\title{
Transformation of the Role of the State Cultural Policy in Contemporary History of Russia
}

\author{
Vladimir S. Luzan* \\ Siberian Federal University \\ 79 Svobodny, Krasnoyarsk, 660041, Russia
}

Received 21.03.2017, received in revised form 17.08.2017, accepted 24.08.2017

The article attempts to reveal the transformation of the role of the state cultural policy in the Russian Federation within the period of modern history, starting from the first decade of the XXI century when the state system of cultural processes management as well as the major factors that determine this transformation were finally formed.

The article states that the analysis of classical and modern Russian studies of cultural policy affirms the validity of the interdisciplinary research of this multidimensional object.

In conclusion the author outlines the general provisions and probable trends in the development of the state cultural policy of Russia in modern geopolitical situation.

Keywords: cultural policy, culture, self-identity, subjects of cultural policy, cultural institutions, state authorities, local self-government.

DOI: 10.17516/1997-1370-0135.

Research area: culture studies.

\section{Introduction}

In the age of globalization and pressure of other civilizations it becomes apparent that further development of the Russian Federation as one of the leading states and equal members of the world community is possible only when culture becomes one of the most important national priorities at the state level in addition to the geopolitical influence restoration and the civil society formation. Besides, Russia's return to the countries, which actively influence the development of modern civilization, is impossible in principle without the appropriate national cultural policy. This is largely due to the fact that the state cannot have a significant impact on global geopolitical processes if it does not have a clear internal ideal-creating process on a national scale, the main result being the formation of the population's cultural self-identity. This can be illustrated by the example of the contemporary history of Russia from the year of 1991. In general, it should be noted that current geopolitical ambitions of the Russian Federation can be one of the aspects of constructing Russian national identity due to historic circumstances.

(c) Siberian Federal University. All rights reserved

* Corresponding author E-mail address: vladimir_luzan@list.ru 
Awareness of all these factors has resulted in revitalization of domestic research interest to the analysis of the transformation of the role of the state cultural policy in the contemporary history of Russia. Besides, the subject chosen is relevant due to a set of vital problems peculiar for the Russian socio-cultural reality:

- inability of the current system of the "culture" branch to form value orientations, relevant to the modern needs of society, at the national level;

- lack of formed and complete image of the country's culture and importance of diversity of cultures of the peoples inhabiting the Russian Federation for its formation;

- lack of an opportunity for effective and largescale implementation of innovative technologies in existing traditional institutions of culture, which is one of the main factors determining comfort and accessibility of these institutions for all citizens, including disabled people;

- lack of the majority of citizens' understanding that culture is not so much and not only entertainment but the only social institution functioning to ensure educational influence on an individual, his / her harmonious development formation, assistance in positive socialization and, most importantly, national identity.

In present research cultural policy is a "system of human activities with clear goals, effective methodology for their implementation, real actions for creation, maintenance and translation of the most important cultural ideals (standards) and their implementation in sociocultural reality".

This definition avoids identification with the activities of the state only. It suggests that cultural policy has a source in the form of objectively existing social process carried out by various social actors".

At the same time, the relevance of identifying the transformation of the role of the state cultural policy in the contemporary history of Russia is determined by several factors:

1) Until recently, cultural policy and the "culture" branch as integral parts of the sociocultural sphere, including education, health care, youth policy, physical culture and sport, social safety net, tourism, have undergone the least structural reforms and changes, with the exception of separation of powers within the formation of a federative type of government and the reform of local government. Active reformation of related industries of socio-cultural sphere (for example, education) has led to the situation of particularly acute need to develop a conceptual vision of not only state cultural policy as a whole but its separate areas as well.

2) For the first time in the contemporary history of Russia the Decree of the President of the Russian Federation No. 808 dated 24.12.2014 approved "The Framework of the State Cultural Policy of the Russian Federation", a fundamental document that defines the conceptual provisions of the cultural policy development in the short and long-term perspectives as well as the tasks of the state in this field. However, the process of developing a strategic document on implementation of the Framework of cultural policy lasted till the beginning of 2016 and was accompanied by serious disputes not only in the expert community but also between different executive authorities, primarily the Ministry of culture and the Ministry of Finance of the Russian Federation. The efforts made resulted in the Strategy of the state cultural policy for the period up to 2030 approved by the order of the Government of the Russian Federation No. 326-p dated 29.02.2016.

3) To date, a normative legal base has been formed. It defines the functioning of most traditional actors of cultural policy and is aimed at implementing the citizens' constitutional rights in the sphere of culture. At the same 
time, the revision of existing regulatory legal acts providing implementation of the state cultural policy is required, the acts aiming at consolidation of the state functions of the cultural policy implementation but not at a statement of departmental, sectoral approach to the cultural policy implementation.

4) It is worth while noting that a transitional period of implementation of the Federal law № 131-FZ “On general principles of local self-government organization in the Russian Federation" dated 06.10 .2003 was over in January 2009. As a result, all its provisions came into force on the territory of all constituent entities of the Russian Federation. This means that the process of large-scale decentralization of the system of the traditional cultural institutions management was over. It formed three distinct levels of the cultural policy implementation: the federal level with the Ministry of culture of the Russian Federation at the head; the regional level with the executive authorities in the sphere of culture of the Russian Federation at the head; the municipal level with the bodies of cultural municipalities, which often do not exist in the structure of the municipal executive bodies or are integrated in the multi-purpose departments, offices, etc. Therefore, it is possible to state the crystallization of modern multi-level system of cultural processes management and its final decentralization.

5) Emergence of many new subjects of cultural policy within the period of contemporary history of Russia, the subjects being individuals (independent creators, managers in the sphere of culture, etc.), social groups, parties, institutions of different forms of ownership, which take active, conscious participation in the cultural development often for the sole purpose of financial gain. Therefore, we can state the beginning of the process of competition between the subjects of cultural policy not only for the visitors in terms of physical presence, but also for their financial resources. This is especially relevant for state and municipal entities of the cultural policy, which do not meet such competition with private organizations due to various reasons.

It cannot be but mentioned that specialized socially oriented non-commercial organizations play an increasingly important role as one of the main actors of cultural policy due to an active development of civil society in the Russian Federation.

6) Emergence of the process of conceptual revision of the sectoral approach of the state to culture in 2014 and understanding of its interdepartmental nature, if cultural policy is viewed from the perspective of state administration. According to a new forming approach, cultural policy can be interpreted as "the system of human activities with clear goals, effective methodology for their implementation, real actions for creation, maintenance and translation of the most important cultural ideals and their implementation in the socio-cultural reality by various actors of the socio-cultural sphere" ${ }^{2}$. Transfer of powers in the field of tourism activities to the Ministry of culture of the Russian Federation in 2013, i.e. integration of new administrative entities in the cultural development, can indirectly serve a proof of the beginning of such changes in the conceptual approaches to culture in addition to adopting fundamental strategic documents.

7) Development of fundamentally new methodological recommendations to the subjects of the Russian Federation and local government authorities on the cultural organizations network development and providing the population with the cultural organizations' services at the state level, the recommendations being approved by the Order of the Ministry of culture of the Russian Federation No. P-948 dated 27.07.2016. In these recommendations the state officially 
recognizes the existence of subjects of cultural policy of private ownership and makes them an integral part of cultural development.

It should be noted that the comparison between different scientific and management approaches to the implementation of the state cultural policy suggests that until recently the absence of the state's clear positions on this matter, manifested both in conceptual terms and in the realities of public cultural policies, has negatively influenced the entire infrastructure of the sociocultural life of the Russian society. In this regard, under the existing historical circumstances it is necessary for each new generation of citizens to assimilate the former and develop a new toolkit of shared values and norms, reinterpreted in everchanging particular historical conditions.

The problem of the absence, until recently, of the conceptual vision of the state cultural policy implementation at all levels (federal, regional, municipal) and its role in social development is, undoubtedly, cultural in its nature. This fact turns it into the subject of scholarly attention in a number of humanities (political science, sociology, anthropology, art studies, philosophy, theory and history of cultural-educational and socio-cultural activity, etc.).

\section{Methodology}

Culturological expertise of the Russian state cultural policy, carried out by S.S. Zagrebin, is of a particular interest. He notes that "culturological definitions of cultural policy are kind of ideal models, built on the principle of deep abstraction from concrete historical realities"3. As for the applied aspect, it is limited to "departmental understanding of culture, which regards cultural policy as the activities of regional departments of culture towards the institutions of culture and art"4.

The empirical understanding of culture has historically formed in Russian realities. It is associated primarily with the practice of educational and creative activities as well as "gathering" and studies of tangible and intangible cultural heritage. This, in particular, is suggested by Iu.V. Osokin who writes that "this empirical understanding of culture has found its expression in specialization towards a number of special research and training institutions - institutions of culture (the former developed the issues concerning, primarily, the activity of clubs and libraries as well as amateur art; the latter trained the specialists in the field of cultural-educational and cultural-mass work who are mostly librarians and those employed in clubs)"s.

E.V. Vinokurov, researching the problems of cultural policy formation in the places of the indigenous peoples' residence, rightly pointed out that "isolation of cultural studies from real cultural processes is due to two main reasons: insufficient scientific validity of state cultural policy, the tasks of which are formulated rather declaratively, and lack of regional applied culturological studies of cultural policy, enriching theoretical cultural studies".

In addition, such classic research methods as analysis and synthesis, induction and deduction are actively applied.

An empirical base of the research is constituted of:

- normative legal acts regulating the sphere of cultural policy;

- programs, strategies and other official documents aimed at the development of culture, both at the federal and regional levels;

- regulations of the Ministry of culture of the Russian Federation and regional executive bodies in the field of culture.

Thus, the diversity of the state cultural policy has led to the interdisciplinary type of research.

\section{Theoretical basis}

The interdisciplinary approach to revealing the dynamics of the state cultural policy of the 
Russian Federation has led to the reference to the research works in various scientific and theoretical fields. In particular, the author bases on the Russian researchers' works, reflecting the problems of cultural policy formation not only in current realities but also in the Soviet period (P.S. Gurevich, V.K. Egorov, L.B. Kogan, V.A. Kurennoi, E.S. Markarian, V.M. Mezhuev, K.E. Razlogov, K.A. Uledov, Iu.U. FokhtBabushkin, et al.).

A wide range of problems concerning the functioning of culture in modern society is dwelt upon in the works, shaping the modern view on culture as a regulator of the society's economic and socio-cultural life (M.B. Gnedovskii, B.S. Erasov, L.G. Ionin, M.S. Kagan, G.G. Karpova, O.V. Kostina, N.P. Koptseva, Ch. Landry, F. Matarasso, E.A. Orlova, M. Pachter, D. Trosby, A.Ia. Flier, L. Harrison, I.G. Iakovenko, et al.).

In addition, in the thesis the author bases on works on economic, organizational, legal and management aspects of the "culture" industry functioning (T.V. Abankina, G.A. Avanesova, O.N. Astaf'eva, T.G. Bogatyreva, G.M. Galutsky, O.I. Genisaretskii, N.M. Genova, V.S. Zhidkov, G.P. Ivliev, E.L. Ignat'eva, E.L. Kudrina, A.N. Panfilov, K.E. Razlogov, A.Ia. Rubinshtein, G.L. Ruksha, B.Iu. Sorochkin, et al.).

A.I. Arnol'dov, N.F. Buchilo, G.N. Volkova, E.V. Il'enkova, B.I. Kaverina, V.A. Lektorskii, V.P. Malakhov, V.S. Stepin, A.N. Chumakov, V.G. Iudin, et al. are worth being mentioned among the Russian philosophers focusing on certain problems of implementation of cultural policy and culture in general. These authors considered cultural policy mainly through the correlation of the categories of an individual's consciousness development in the process of his / her activity potential formation and in the perspective of the dependence of culture on the social determination of cognition.
A significant place in this thesis is held by the scholars developing the sociology of culture (L.D. Gudkov, B.V. Dubin, A.G. Dugin, S.A. Erofeev, N.L. Zakharov, L.G. Ionin, K. Mannheim, T. Parsons, P. Sorokin, A.I. Shendrik, et al.). Diversity of approaches, attitudes, ideas on the sociology of culture as a field of scientific knowledge and academic discipline is worth mentioning. This diversity reflects the ongoing Russian and foreign scientific discussions on the subject of the sociology of culture, its place in the structure of sociological knowledge and in the system of cultural sciences.

Foreign experience of cultural policy formation and implementation and the role of culture in general, including the regional context, are dwelt upon in the works by the galaxy of foreign authors (F. Bianchini, C. Geertz, E. Grosjean, M. Dragicevic-Sesic, B. Malinowski, M. Pike, A. Radcliffe-Brown, John Tammany, L. White, D. Hesmondalgh), materials of various state institutions and publications of Russian researchers (E.E. Beliaeva, S.E. Zuev, Iu.V. Nikolaeva, A.S. Skachkov, V.R. Firsov, O.V. Khlopina, P.G. Shchedrovitskii, et al.

It should be noted that in the period of contemporary history of Russia the issue of the state cultural policy formation is the subject of numerous theses: A.S. Balakshin, P.L. Volk, L.E. Vostriakov, Iu.E. Ziiatdinova, M.I. Krivosheev, E.V. Kuznetsova, N.N. Kurnaia, G.A. Smirnov, S.P. Shevchukov, et al.

\section{Results}

The dynamics of cultural policy in the Russian Federation in the conditions of global transformations is determined by a new round of the return of the state as one of the most active subjects of cultural development. First and foremost, adoption of a number of fundamental documents that define the state's vision of the requirements and value orientations of modern 
cultural development is a direct confirmation of this, the documents being the following ones:

1. "The Framework of the State Cultural Policy of the Russian Federation", approved by the Decree of the President of the Russian Federation No. 808 dated 24.12.2014;

2. "The Strategy of the State Cultural Policy for the Period up to 2030", approved by the Decree of the Government of the Russian Federation No. 326-p dated 29.02.2016;

3. The action plan for the implementation of the Strategy of the state cultural policy for the period up to 2030 in the course of 2016-2018, approved by the Decree of the Government of the Russian Federation No. 2563-p dated 01.12.2016;

4. The conception of the theatrical business long-term development in the Russian Federation for the period up to 2020, approved by the Decree of the Government of the Russian Federation No. 1019-p dated 10.06.2011;

5. The conception of the circus business development in the Russian Federation for the period up to 2020, approved by the Decree of the Government of the Russian Federation No. 434-p dated 02.04.2012;

6 . The strategy of the tourism development in the Russian Federation for the period up to 2020, approved by the Decree of the Government of the Russian Federation No. 941-p dated 31.05.2014;

7. The conception of the concert activities development in the field of classical music in the Russian Federation for the period up to 2025, approved by the Decree of the Government of the Russian Federation No. 2395-p dated 24.11.2015;

8 . The draft of the conception of the museum business development in the Russian Federation for the period up to 2030;

9. The action plan of the Ministry of culture of the Russian Federation for the years 20162021, approved by the Order of the Ministry of culture of the Russian Federation No. 2296 dated 13.10.2016;
10. Methodical recommendations to the subjects of the Russian Federation and local self-government authorities on the development of a network of cultural organizations and provision of the cultural organizations' services to the population, approved by the Order of the Ministry of culture of the Russian Federation No. P-948 dated 27.07.2016.

In addition, the All-Russian public-state organization "Russian Fund of Culture" was established by the Decree of the President of the Russian Federation No. 581 dated 31.10.2016 in order to implement the Framework of the state cultural policy. Its activity is aimed at:

- consolidation of efforts of the state and civil society to create the conditions for encouraging the population to creative self-realization;

- preservation of cultural values;

- revival of cultural traditions;

- promotion of Russian culture;

- support of the development of the cultural potential of the subjects of the Russian Federation.

At this stage it is impossible to evaluate the effectiveness of the establishment of such structures and their activity due to the lack of results. However, it is possible to register the end of the period of the state's dissociation from the conceptual definition of the foundations of its own cultural policy at the federal level. Therefore, Russia has travelled a long way from its initial maximum deliverance as a dominant subject from the administrative, financial and ideological burden and switching its major focus on solving social and economic problems and development of the framework of the state cultural policy relevant to modern conditions over the 25 years of its independent existence in the sphere of cultural policy.

Thus, in the USSR period the main objective of cultural policy was first and foremost the citizens' ideological education in line with the communist ideals. At that the subjects of cultural 
policy did not have the problem of funding and searching for economic solutions as the state was the sole subject itself. The cultural institutions received the funds, required for the realization of their ideological function. from the state budget.

In the period of "perestroika" (1986-1991) the cultural institutions were set an objective to increase the scale of profit forms of cultural activities without losing their ideological function. This, consequently, changed the attitude to business activity. The cultural institutions were financed from the budget but were interested in finding additional off-budget funds.

Finally, from 1991 when the economic system began its shift to market relations and the political system became pluralistic and multiparty the state became unable to fulfill former obligations to its own cultural institutions. This situation led to the emergence of private actors of the cultural policy and, later, to the administrative reform, which resulted in the situation when the state finally shook off the financial and managerial burden by separating the powers in the field of culture at the federal, regional and municipal levels.

However, direct budget funding is still prevailing in the system of financing the culture of the Russian Federation, whereas other sources of funding available for foreign cultural institutions do not exist. It should be noted that the increase in financial soundness of modern state and municipal institutions of culture is one of the main conceptual provisions of the framework of cultural policy. According to the data of the Main Information and Computing Centre of the Ministry of culture of the Russian Federation (the year 2014), the share of budget financing in the total financial income of the Russian institutions of culture and art made $73.1 \%$ for theaters, $80.2 \%$ for museums, $78.6 \%$ for concert organizations, $91.2 \%$ for cultural institutions, $91.1 \%$ for children's art schools, $98 \%$ for libraries?
The use of Russian and foreign advanced practice of the development of multi-channel system of financing the culture under certain economic conditions favours significant offbudget investments and ensures sustainable culture development in modern conditions.

Development and adoption of the abovementioned documents result in the adjustment or development (in case of lack of these documents) of similar documents first at the regional level and then at the municipal one. It is worth while noting that, unlike the federal centre, some of the subjects of the Russian Federation had conceptual documents determining the development of cultural policy in a particular region. For example, the Basic strategy of the cultural policy of the Krasnoyarsk Krai for the years 2009-2020 ${ }^{8}$ was approved by the Resolution of the Government of the Krasnoyarsk Krai No. 24-п dated 20.01.2009.

In general it can be stated that the state returned to the understanding that the country's economic and social modernization in a historically short period as well as transition to an intensive way of development ensuring the readiness of the state and society to meet the challenges of the modern world seem to be impossible without investment in human capital, the culture being the main instrument of such investments.

The most dangerous negative factors that may have a significant impact on the future of Russia are the following:

- diffusion of traditional Russian spiritual and moral values and weakening of the unity of the multinational people of the Russian Federation by foreign cultural and informational expansion;

- decline in the citizens' intellectual and cultural level;

- devaluation of common values;

- growth of aggression and intolerance, antisocial behavior; 
- atomization of the society, i.e. breakdown in social bonds, growth of individualism and disdain for the rights of others;

- propaganda of permissiveness and violence, racial, national and religious intolerance;

- reducing the role of the Russian language, the quality of its teaching in the Russian Federation and abroad;

- attempts of the Russian and world history falsification.

Another negative factor, significantly affecting the development of the Russian Federation, is a threat to the unity of the cultural space due to the insufficient use of the potential of culture as a factor of socio-economic development of Russia, its national security and territorial integrity. In the conditions of increasing globalization processes and active foreign cultural and informational expansion culture is the main tool for the formation and strengthening of civic identity, ensuring the Russian nation's unity, preserving the unity of the cultural and linguistic space of the Russian Federation.

At the same time, regional disproportions in access to the services of cultural institutions, expenditures on culture, infrastructure development also form the risks for the uniform cultural space preservation. Regional disproportions in the development of culture are manifested depending on the availability of cultural facilities, funding and access to cultural heritage for great masses of population. Despite the fact that the regional differentiation of expenditures on culture and arts as a percentage of the gross regional product shows a recent tendency to decrease (from 10 times in 2010 to 6,5 times in 2013), whereas regional differences in security and infrastructure development remain significant ${ }^{9}$.

\section{Conclusions}

In the current situation a significant part of the Russian managerial elite, public groups and institutions has realized the fact that cultural policy is an independent interdisciplinary type of the state policy the implementation of which will enable to preserve the Russian society and, as a consequence, the state as a whole in the short term prospect and ensure the position of the Russian Federation in the global geopolitical arena as an independent Eurasian civilization, which occupies a marginal position between the cultures of the West and the East, in the long term prospect. Awareness of this fact will increase the influence of the state on the ongoing cultural processes in the short and long term prospects and might cause the attempts of new centralization of the "culture" branch management system. These processes, in their turn, will destine a new round of confrontation between the creators and managers of culture.

Formation of the Russian national state is possible on the basis of the formation of specific Russian nationalism, in which integrated cultural products are claimed as the ethno-cultural basis, the products removing the contradictions of the cultural heritage of those ethnic groups involved in the process of a national state creation. A special control of the political power over the processes of local bourgeois elites' formation in the national republics is essential.

Luzan, V.S. (2011). Sotsial'no-filosofskii analiz dinamiki gosudarstvennoi kul'turnoi politiki Rossiiskoi Federatsii: avtoref. dis... kand. filos. nauk [Socio-Philosophical Analysis of the Dynamics of State Cultural Policy of the Russian Federation: Abstract of the PhD thesis in Philology]. Krasnoyarsk, $24 \mathrm{p}$.

2 Ibid.

3 Zagrebin, S.S. (2008). Kul'turologicheskaia ekspertiza v sisteme kul'turnoi politiki sovremennogo rossiiskogo gosudarstva [Culturological Expertise in the System of Cultural Policy of Modern Russian State]. Fundamental'nye problemy kul'turologii. Tom IV [Fundamental Problems of Cultural Studies. Vol. IV]. Moscow, Alateiia, 54-58.

4 Ibid., p. 56. 
Osokin, Iu.V. (2007). Kul'turologiia. Entsiklopediia v 2 t. T. 1 [Cultural Studies. Encyclopedia in 2 vol. Vol. 1]. Moscow, ROSSPEN, p. 1072.

${ }_{6}$ Vinokurova, E.P. (2011). Kul'turnaia politika v Respublike Sakha (Iakutiia): etnokul'turnye i geokul'turnye osobennosti: dis. ... kand. kul'tur [Cultural Policy in the Republic of Sakha (Yakutia): Ethnic, Cultural and Geo-Cultural Peculiarities: Thesis of PhD in Culturology]. Moscow, p. 15.

7 Strategiia gosudarstvennoi kul'turnoi politiki na period do 2030 goda, utverzhdennaia Rasporiazheniem Pravitel'stva Rossiiskoi Federatsii ot 29.02.2016 № 326-p [The Strategy of the state cultural policy for the period till 2030, approved by Decree of the Government of the Russian Federation No. 326-p dated 29.02.2016]. Spravochnaia pravovaia sistema "Konsul'tantPlus" [Question-answering legal system "ConsultantPlus"].

8 Question-answering legal system "ConsultantPlus".

$9 \quad$ Strategiia gosudarstvennoi kul'turnoi politiki na period do 2030 goda, utverzhdennaia Rasporiazheniem Pravitel'stva Rossiiskoi Federatsii ot 29.02.2016 № 326-p [The Strategy of the state cultural policy for the period till 2030, approved by Decree of the Government of the Russian Federation No. 326-p dated 29.02.2016]. Spravochnaia pravovaia sistema "Konsul'tantPlus" [Question-answering legal system "ConsultantPlus"].

\section{References}

Alexander, D., Smith, F. (2010). Sil'naia programma v kul'tursotsiologii [The Strong Programme in Cultural Sociology], In Sociological Review, 9 (2), 11-30.

Arnol'dov, A.I. (2004). Kul'turnaia politika: realii i tendentsii [Cultural Policy: Realities and Trends]. Moscow, Moscow State University, $64 \mathrm{p}$.

Aron, R. (2000). Izbrannoe: Vvedenie v filosofiu istorii [Selected Works: Introduction to the Philosophy of History]. St. Petersburg, Universitetskaia Kniga, 543 p.

Astaf'evaa, O.N. (2002). Sinergeticheskii podkhod k issledovaniiu sotsiokul'turnykh protsessov: vozmozhnosti i predely [The Synergetic Approach to the Study of Socio-Cultural Processes: Opportunities and Limits]. Moscow, Izd-vo MGIDA, 295 p.

Astaf'ev, O.N. (2010). Kul'turnaia politika: teoreticheskoe poniatie $i$ upravlencheskaia deiatel'nost': lektsii [Cultural Policy: a Theoretical Concept and Management Activities: Lectures]. Moscow, Izd-vo RAGS, 228 p.

Avdeeva, Iu.N., Libakova, N.M. (2015). Mezhdunarodnye praktiki sotsiokul'turnogo proektirovaniia po otnosheniiu k korennym malochislennym narodam Severa, Sibiri i Dal'nego Vostoka [International Practices of Socio-Cultural Design in Relation to the Indigenous Peoples of the North, Siberia and the Far East], In Sociodynamics, 10, 10-38.

Bakhova, N.A. Koptseva, N.P., Luzan, V.S., Pimenov, N.N., Semenov, A.A., Sertakova, E.A. (2012). Ethno-Formative Mechanisms and Forms of Self-Awareness of Indigenous Peoples under Conditions of External Civilization Pressure (by an example of the Yakut Ethnic Group), In Journal of Siberian Federal University. Humanities \& Social Sciences, 7, 988-1004.

Balakshin, A.S. (2006). Kul'turnaia politika: teoriia i metodologiia issledovaniia: dis. ... d-ra filos. nauk [Cultural Policy: Theory and Methodology of the Research: Thesis of Doctor in Philosophy]. N. Novgorod, $358 \mathrm{p}$.

Bogatyreva, T.G. (2002). Globalizatsiia i imperativy kul'turnoi politiki sovremennoi Rossii [Globalization and the Imperatives of Cultural Policy of Modern Russia]. Moscow, TEIN, 179 p.

Bystrova, A.N. (2004). Kul'turnoe prostranstvo kak predmet filosofskoi refleksii [Cultural Space as an Object of Philosophical Reflection], In Philosophical Sciences, 12, 39.

Chartrand, H.H., McCaughey, C. (1989). The Art's Length Principle and the Arts: An International Perspective - Past, Present and Future, In Who's to Pay for the Arts: The International Search for Models Support., 4. American Council for the Arts, 43-80.

Doklad Obshchestvennoi palaty Rossiiskoi Federatsii "Kul'tura i budushchee Rossii. Novyi Vzgliad" na plenarnom zasedanii Obshchestvennoi palaty Rossiiskoi Federatsii ot 24 noiabria 2007 
goda [The Report of the Public Chamber of the Russian Federation "Culture and Future of Russia. A New View" at the Plenary Session of the Public Chamber of the Russian Federation dated November 24, 2007]. Available at: http://www.dokladoprfcultura.ru (accessed 10 August 2014).

Genova, N.M. (2011). Kul'turnaia politika v sisteme infrastruktury kul'tury regiona [Cultural policy in the System of the Regional Culture Infrastructure]. Omsk, Omsk State University, $287 \mathrm{p}$.

Hesmondhalgh, D., Nisbett, M., Oakley, K., Lee, D. (2015). Were New Labour's Cultural Policies Neo-Liberal? In International Journal of Cultural Policy, 21 (1), 97-114.

Iampol'skaia, E.A. (2016). O kul'ture i ne tol'ko [On Culture and More]. Moscow, Gorodets, 590 p.

Ilbeikina, M.I., Kolesnik, M.A., Libakova, N.M., Sitnikova, A.A. (2015). Global and Local Trends in Development of Siberian City of Krasnoyarsk, In Mediterranean Journal of Social Sciences, 6 (3), 241-248.

Intellektual'nyi dosug kak factor ustoichivogo razvitiia urbanizirovannoi territorii (na material Krasnoiarskogo kraia): kollektivnaia monografiia [Intellectual Leisure as a Factor of the Urban Territory Sustainable Development (as Exemplified by the Krasnoyarsk Krai): Collective Monograph; A.V. Andreev, V.S. Luzan, A.F. Morozov, E.A. Nozdrenko, I.A. Panteleev, E.A. Rukavitsyna. Krasnoyarsk, Siberian Federal University, 480 p.

Ivliev, G.P. (2012). Kul'turnaia politika i razvitie zakonodatel'stva o kul'ture v Rossiiskoi Federatsii: stat'i $i$ vystupleniia [Cultural Policy and Development of Legislation on Culture in the Russian Federation: Articles and Speeches]. Moscow, Norma, INFRA-M, 208 p.

Kistova, A.V., Pimenova, N.N., Zamaraeva, Iu.S., Reznikova, K.V. (2014). Research Possibilities for Studying the Indicators of Quality of Life of Indigenous Peoples of the North (Based on the Study of Indigenous Peoples of the North of Russia), In Life Sci J., 11(6s), 593-600.

Kolesnik, M.A. (2016). Konstruirovanie russkoi kul'turnoi identichnosti: kontseptual'nyi $i$ metodologicheskii podkhody: avtoref. dis. ... kand. kul'turologii [The Russian Cultural Identity Design: Conceptual and Methodological Approaches: Abstract of Thesis of PhD in Cultural Studies]. Krasnoyarsk, 20 p.

Kolesnik, M.A., Koptseva, N.P., Luzan, V.S., Libakova, N.M., Sertakova E.A., Sergeeva N.A. (2016). Economic Migration in Central Siberia and Ethnic Conflict Risks (Based on Krasnoyarsk Krai Analysis), In International Journal of Economics and Financial Issues, 6 (5S), 104-108.

Koptseva, N.P. (2012a). Culturological Base of Formation of National Russian Identity in the Siberian Regions of the Russian Federation, In Science Journal of Volgograd State University. Series 7. Philosophy, Sociology and Social Technologies, 3, 11-15.

Koptseva, N.P. (2012b). Metodologicheskie vozmozhnosti sotsial'noi (kul'turnoi) antropologii dlia sovremennykh kul'turnykh issledovanii [Methodological Opportunities of Social (Cultural) Anthropology for Modern Cultural Studies], In Filosofiia i kul'tura [Philosophy and Culture], 10, 9-18.

Koptseva, N.P. (2012c). The Problem of Methodology of Modern Cultural Researches: Opportunities of Classical Britain Social Anthropology, In The Humanities and Social Sciences, 4, 89-104.

Koptseva, N.P. (2014a). K voprosu o kontseptual'nykh osnovaniiakh stroitel'stva obshchenatsional'nogo rossiiskogo gosudarstva [On the Conceptual Base of the Construction of the Russian National State], In NB: Problemy Politiki i Obshchestva [NB: Problems of Policy and Society], 1, 1-14. Available at: http://e-notabene.ru/pr/article_10928.html (accessed 01 August 2015). 
Koptseva, N.P. (2014b). Expert Analysis of the Main Trends of Northern Siberia's Indigenous Small-Numbered Peoples Economic Development, In Economic Annals-XXI, 11-12, 93-96.

Koptseva, N.P. (2015). The Current Economic Situation in Taymyr (the Siberian Arctic) and the Prospects of Indigenous Peoples' Traditional Economy, In Economic Annals-XXI, 9-10, 95-97.

Koptseva, N.P., Bakhova, N.A., Zamaraeva, Iu.S., Kirko, V.I. (2012). The Problem of Social and Cultural Studies at Contemporary Human Sciences, In Modern Problems of Science and Education, 3. Available at: http://www.science-education.ru/ru/article/view?id=6183 (accessed 31 July 2016).

Koptseva, N.P., Kistova, A.V. (2015). Construction of Ethnocultural and National Identity as a Philosophical Problem, In Philosophy and Culture, 1, 12-19.

Koptseva, N.P., Kirko, V.I. (2014a). Processes of Acculturation Khakases (Indigenous People of Southern Siberia), Living Outside of the Khakassia in the Urban and Student Environment], In American Journal of Applied Sciences, 11 (12), 1969-1975.

Koptseva, N.P., Kirko, V.I. (2014b). Ethic Identification of Indigenous People of the Siberian Arctic, In American Journal of Applied Sciences, 11 (12), 1969-1975.

Koptseva, N.P., Kirko, V.I. (2014c). Some Concepts of Late Nineteenth and Early TwentiethCentury Russian Philosophy, Revealing Specific Forms of Collective Identities [Algunos conceptos de la filosofía rusa de finales del siglo XIX y primer tercio del siglo XX, que revelan formas específicas de las identidades colectivas], In Revista de Filosofia, 76 (1), 7-31.

Koptseva, N.P., Kirko, V.I. (2014d). Post-Soviet Practice of Preserving Ethnocultural Identity of Indigenous Peoples of the North and Siberia in Krasnoyarsk Region of the Russian Federation, In Life Sci J.,11(7), 180-185.

Koptseva, N.P., Kirko, V.I. (2014e). Specificity of Ethnogeny Indigenous Peoples by Central Siberia in the Transition from the Traditional Type of Society to Modern Society, In Life Sci J., 11(7), 409-413.

Koptseva, N.P., Kirko, V.I. (2014f). Modeling of the Basic Processes and Traditional Way of Life of Indigenous Peoples of Krasnoyarsk Region (Eastern Siberia), In Life Sci J., 11(10), 489-494.

Koptseva, N.P., Kirko, V.I. (2014g). Modern specificity of legal regulation of Cultural Development of the Indigenous Peoples of the Arctic Siberia under the global transformations, In Life Sci J., 11(9), 314-319.

Koptseva, N.P., Kirko, V.I. (2015a). The Impact of Global Transformations on the Processes of Regional and Ethnic Identity of Indigenous Peoples Siberian Arctic, In Mediterranean Journal of Social Sciences, 6 (3), 217-224.

Koptseva, N.P., Kirko, V.I. (2015b). Aspects of Political Wisdom in the Treatise Lao Tzu "Tao Te Ching”, In Mediterranean Journal of Social Sciences, 6 (5S2), 119-126.

Koptseva, N.P., Kirko, V.I., Zamaraeva, J.S. (2015). Characteristic Features of Ethnic Labor Migration in the Krasnoyarsk Krai (Central Siberia, Russia), In International Journal of Economics and Financial Issues, 5, 100-108.

Koptseva, N.P., Libakova, N.M. (2014). Hygiene as a Cultural-Anthropological Practice for Conservation and Transmission of Culture of the Indigenous Minorities of the North, Siberia and the Far East of Russia, In Modern Problems of Science and Education, 2, 646.

Koptseva, N.P., Libakova, N.M., Sertakova, E.A., Luzan, V.S., Kolesnik, M.A., Sergeeva, N. (2016). Brand-Management of Siberian Cities (Krasnoyarsk as a Case Study), In International Review of Management and Marketing, 6 (S5), 185-191. 
Koptseva, N.P., Luzan, V.S. (2012a). Gosudarstvennaia kul'turnaia politika v Sibirskom federal'nom okruge: kontseptsii, problem, issledovaniia [State Cultural Policy in the Siberian Federal District: Conceptions, Problems, Research]. Krasnoyarsk, Siberian Federal University, 183 p.

Koptseva, N.P., Luzan, V.S. (2012b). Modelirovanie kul'tury I kul'turnoi politiki v russkoi filosofii kontsa XIX - pervoi treti XX vv. [Modelling of Culture and Cultural Policy in Russian Philosophy at the End of the XIX - First Third of the XX Centuries], In Philosophy and Culture, 4 (52), 105-116.

Koptseva, N.P., Luzan, V.S., Razumovskaya, V.A., Kirko, V.I. (2016). The Content Analysis of the Russian Federal and Regional Basic Legislation on the Cultural Policy, In International Journal for the Semiotics of Law, 29 (2), 1-28.

Koptseva, N.P., Reznikova, K.V. (2015). Refinement of the Causes of Ethnic Migration North Selkups Based on the Historical Memory of Indigenous Ethnic Groups Turukhansk District of Krasnoyarsk Krai, In Bylye Gody, 4 (38), 1028-1038.

Koptseva, N.P., Reznikova, K.V., Dobryaeva, I.S. (2015). The Methodology of Natural Sciences in Antiquity and the Second Book of Galen's de Placitis Hippocratis et Platonis, In Schole, 9 (1), 45-44.

Koptseva, N.P., Sertakova, E.A. (2015). Sotsiokul'turnoe prostranstvo sovremennogo rossiiskogo goroda (na material analiza goroda Krasnoiarska) [Socio-Cultural Space of a Modern Russian City (Based on the Analysis of the City of Krasnoyarsk)]. Krasnoyarsk, Siberian Federal University, 128 p.

Kostina, A.V. (2010). Kul'turnaia politika sovremennoi Rossii: sootnoshenie etnicheskogo $i$ natsional'nogo [Cultural Policy of Modern Russia: the Relation between Ethnic and National]. Moscow, URSS: Izdatel'stvo LKI, 238 p.

Kozin, N.G. (2008). Universal'nyi proekt tsivilizatsionnoi identichnosti Rossii [Universalistic Project of Civilized Identity of Russia], In Philosophy and Society, 4, 75.

Krivosheev, M.I. (2004). Modernizatsiia kul'turnoi politiki $v$ kontekste garmonizatsii individual'nykh i obshchestvennykh interesov: Rossiia v nachale XXI stoletiia: diss. ... kand. kul'turol. nauk [Modernization of Cultural Policies in the Context of Harmonizing Individual and Social Interests: Russia in Early XXI century: Thesis of PhD in Cultural Studies]. Moscow, 138 p.

Kuznetsova, E.V. (1999). Kul'turnaia politika Rossii (Teoriia, istoriia i sovremennost'): diss. ... kand. kul'turol. nauk [Cultural Policy of Russia (Theory, History and the Present)]: Thesis of PhD in Cultural Studies]. Moscow, 134 p.

Lee, H. (2015). Branding the Design City: Cultural Policy and Creative Events in Seoul, In International Journal of Cultural Policy, 21 (1), 1-19.

Libakova, N.M. (2011). Modifikatsiia gendernykh obrazov v rossiiskoi kul'ture kontsa XIX nachala XXI vv.: diss. ... kand. filos. nauk [Modification of Gender Images in the Russian Culture at the End of the XIX-Beginning of the XXI Century: Thesis of PhD in Philosophy]. Krasnoyarsk, $155 \mathrm{p}$.

Libakova, N.M. (2015a). Formation of the Positive Ethnic Identity of Indigenous Peoples through Decorative and Applied Art (Bone Carving), In Modern Problems of Science and Education, 1, 1889.

Libakova, N.M. (2015b). Upravlenie zdravookhraneniem dlia korennykh narodov Tsentral'noi Sibiri (na material analiza Krasnoiarskogo kraia) [Healthcare Management for the Indigenous Peoples of Central Siberia (Based on the of the Krasnoyarsk Region Study)], In Trends and Management, 4, 380-394.

Libakova, N.M. (2016). Akkul'turatsionnyi stress i tekhnologii ego preodoleniia [Acculturation Stress and Technologies of Overcoming It], In Sociodynamics, 2, 89-97. 
Libakova, N.M. Sertakova, E.A. (2014a). Cultural Study of Indigenous Peoples of the North of the Krasnoyarsk Region: the Results of the Expert Interview, In Modern Problems of Science and Education, 4, 598-607.

Libakova, N.M., Sertakova, E.A. (2014b). Methodology of Applied Ethnological Researches Carried Out in the Northern Territories of Russia: Advantages of Expert's Interview], In NB: Problems of Policy and Society, 3, 67-86.

Libakova, N.M., Sertakova, E.A. (2015). The Method of Expert Interview as an Effective Research Procedure of Studying the Indigenous Peoples of the North, In Journal of Siberian Federal University. Humanities \& Social Sciences, 8 (1), 114-129.

Libakova, N.M., Sitnikova, A.A., Sertakova, E.A., Kolesnik, M.A., Ilbeikina M.I. (2014). Interaction of the Yakut Ethnicity and Biological Systems in the Territory of the Sakha Republic (Hordogoy Settlement, Suntarsky District) and Krasnoyarsk Krai (Essey Settlement, Evenks District), In Life Sci J., 11 (6s), 585-592.

Luzan, V.S. (2009a). Cultural Policy as Subject of Applied Culture Studies, In Journal of Siberian Federal University. Humanities \& Social Sciences, 3, 323-334.

Luzan, V.S. (2009b). Cultural Policy as a Self-Independent Type of State Policy, In Journal of Siberian Federal University. Humanities \& Social Sciences, 4, 587-594.

Luzan, V.S. (2011a). Sotsial'no-filosofskii analiz dinamiki gosudarstvennoi politiki Rossiiskoi Federatsii: avtoref. dis. ... kand. filos. nauk [Socio-Philosophical Analysis of the Dynamics of the State Cultural Policy in the Russian Federation: Abstract of Thesis of PhD in Philosophy]. Krasnoyarsk, 24 p.

Luzan, V.S. (2011b). Content-Analysis of the Basic Normative Legal Documents, Providing Realization of the State Cultural Policy (Federal and Regional Aspects), In Journal of Siberian Federal University. Humanities \& Social Sciences, 3, 342-362.

Luzan, V.S. (2011c). Peculiarities of Legal Regulation of Socio-Cultural Development of Native Small-Numbered Peoples of the North, Siberia and the Far East under the Conditions of Global Transformations, In Journal of Siberian Federal University. Humanities \& Social Sciences, 5, 678-687.

Luzan, V.S. (2013). Konteksty ponimaniia intellektual'nogo dosuga v sovremennykh rossiiskikh issledovaniiakh [The Contexts of Intellectual Leisure Understanding in Contemporary Russian Studies], In Bulletin of Krasnoyarsk State Pedagogical University named after V.P. Astafiev, 4 (26), 175-178.

Luzan, V.S. (2014a). Role of Business Entities in Social and Cultural Development of Indigenous peoples of the Russian Federation, In Modern Problems of Science and education, 4.

Luzan, V.S. (2014b). Mechanisms of Interaction between the State, Business and Small-Numbered Indigenous Peoples of the Russian Federation under Global Transformations, In Journal of Siberian Federal University. Humanities \& Social Sciences, 8, 1327-1341.

Luzan, V.S. (2014c). Cultural Policy in Northern Territories: Specifics, Problems and Prospects, In Journal of Siberian Federal University. Humanities \& Social Sciences, 9, 1494-1509.

Luzan, V.S. (2015). Peculiarities of Realization of State Cultural Policy in Places Inhabited by Indigenous Peoples of the North, Siberia and the Far East (Russian Federation), In Modern Problems of Science and education, 1.

Luzan, V.S. (2016a). To the Question of the Effect of Cultural Policy upon the Modern Local Identities, In Sociodynamics, 2, 47-66. 
Luzan, V.S. (2016b). Kul'turnaia politika Krasnoiarskogo kraia [Cultural Policy of the Krasnoyarsk Krai]. Krasnoyarsk, Siberian Federal University, 24 p.

Luzan, V.S. (2016c). Osnovy kul'turnoi politiki [The Basics of Cultural Policy]. Krasnoyarsk, Siberian Federal University, 24 p.

Luzan, V.S. (2016d). Rol' profil'nogo obrazovaniia v sfere kul'tury i iskusstva v realizatsii gosudarstvennoi kul'turnoi politiki [The Role of Specialized Education in the Field of Culture and Art in the Implementation of the State Cultural Policy], In Scientific and Methodological Electronic Journal "Concept", 15, 1011-1015. Available at: http://e-koncept.ru/2016/96117.htm.

Luzan, V.S. (2016e). Phenomenon of the Cultural Policy Influence on the Urban Environment Formation in Modern Humanitarian Studies, In Journal of Siberian Federal University. Humanities \& Social Sciences, 6, 1521-1532.

Luzan, V.S. (2016f). Soviet and Post-Soviet Periods in the History of Children's Literature in the Languages of the Indigenous Peoples of the North, Siberia and the Far East, In Journal of Siberian Federal University. Humanities \& Social Sciences, 9, 2060-2070.

Luzan, V.S., Morozova O.F., Nozdrenko E.A., Panteleev I.A., Prokop’eva, G.Iu. (2014). Intellectual Leisure-Time of Krasnoyarsk Region Residents, Potential Development Vectors (Based on the Results of Sociological Research), In Tomsk State Pedagogical University Bulletin, 8 (149), 173-178.

Panfilov, A.N. (2016). Kul'tura i mestnoe samoupravlenie: konstitutsionno-pravovye aspekty vzaimodeistviia [Culture and Local Self-Government: Constitutional and Legal Aspects of Interaction]. Moscow, INFRA-M, 237 p.

Reznikova, K.V. (2012). Sotsial'noe konstruirovanie obshchenatsional'noi identichnosti v Rossiiskoi Federatsii: avtoref. diss. ... kand. filos. nauk [Social Construction of National Identity in the Russian Federation: Abstract of Thesis of PhD in Philosophy]. Krasnoyarsk, 19 p.

Semenova, A.A. (2009). Metodologicheskie vozmozhnosti teorii kul'tury dlia analiza modifikatsii drevnerusskogo kontsepta "gosudarstvo" v rossiiskoi kul'ture XXI veka: avtoref. diss. ... kand. filos. nauk [Methodological Potential of the Theory of Culture for the Analysis of Modifications of the old Russian Concept "State" in the Russian Culture of the XXI Century: Abstract of Thesis of PhD in Philosophy]. Velikii Novgorod, 26 p.

Semenova, A.V., Korsunskaia, M.V. (2010). Kontent-analiz SMI: problemy i opyt primeneniia [Content Analysis of Mass Media: Problems and Practices] / Ed. by V.A. Mansurov. Moscow, Institute of Sociology RAN, 324 p.

Sertakova, E.A. (2012). A. Lefebvre's Cultural Geography in the Context of Humanity Studies of the City Social Space, In Theory and Practice of Social Development. International Scientific Journal, 3, 24-26.

Sertakova, E.A. (2014a). The Concept of the City in Russian culture, In NB: Cultures and Arts, 2, 97-126.

Sertakova, E.A. (2014b). Sotsiokul'turnoe prostranstvo sovremennogo rossiiskogo goroda: na material analiza g. Krasnoiarska: diss. ... kand. filos. nauk [Socio-Cultural Space of Modern Russian City: Analysis of Krasnoyarsk: Thesis of PhD in Philosophy]. Krasnoyarsk, 172 p.

Sertakova, E.A., Avdonina, E.Iu. (2016). Forced Migration and Its Reflection in the Cinematic Art, In Sociodynamics, 2, 106-116.

Sertakova, E.A., Gerasimova, A.A. (2015). The Image of the City of Krasnoyarsk in Xylography, and the Regional Identity Problem, In Urban Studies, 2, 89-99. 
Sertakova, E.A., Gudkova, E.E. (2015). The Value of the Archetype "Angel in a Straitjacket" for Understanding the Specifics of Modern Russian Social and Cultural Space, In Sociodynamics, 4, 64-74.

Sertakova, E.A., Libakova, N.M. (2014). Methodology of Applied Ethnological Researches Carried Out in the Northern Territories of Russia: Advantages of Expert's Interview, In NB: Issues of Society and Politics, 3, 67-86.

Shchedrovitskii, P.G. (2006). Kul'turnaia politika: predposylki peremen [Cultural Policy: Prerequisites of Changes], In Russian Expert Review, 3 (17), 31-33.

Shevchugova, S.P. (2004). Regional'naia sotsial'no-kul'turnaia politika: problem upravleniia $i$ innovatsii: diss. ... kand. sotsiol. nauk [Regional Socio-Cultural Policy: Problems of Control and Innovation: Thesis of PhD in Sociology]. Moscow, $256 \mathrm{p}$.

Transformatsii kul'turnoi politiki v Rossii (1991-2006): annotirovannyi bibliograficheskii ukazatel' [Transformation of Cultural Policy in Russia (1991-2006): Annotated Bibliography] (2008). Moscow, Pashkov Dom, 270 p.

Vinokurova, E.P. (2011). Kul'turnaia politika v Respublike Sakha (Iakutiia); etnokul'turnye i geokul'turnye osobennosti: dis. ... kand. kultur. [Cultural Policy in the Republic of Sakha (Yakutia): Ethno-Cultural and Geo-Cultural Features: Thesis of PhD in Cultorology]. Moscow, $206 \mathrm{p}$.

Volk, P.L. (2005). Sistemno-sinergeticheskaia interpretatsiia kul'turnoi politiki v kontekste kul'turogeneza: dis. ... d-ra kul'turologii [The Systemic-and-Synergetic Interpretation of Cultural Policy in the Context of Cultural Genesis: Thesis of Doctor in Cultural Studies]. Kemerovo, 423 p.

Vostriakov, L.E. (2005). Regional'naia kul'turnaia politika poreformennoi Rossii: sub'ektnoe izmerenie [Regional Cultural Policy of Post-Reform Russia: the Subjective Dimension]. St. Petersburg, Izd-vo SZAGS, 344 p.

Zagrebin, S.S. (2008). Kul'turologicheskaia ekspertiza v sisteme kul'turnoi politiki sovremennogo rossiiskogo gosudarstva [Culturological Expertise in the System of Cultural Policy of the modern Russian State]. Fundamental'nye problemy kul'turologii. Tom IV [Fundamental Issues of Cultural Studies. Vol. IV]. Moscow, Alateiia, 54-58.

Zamaraeva, Iu.S. (2011). Osobennosti sotsiokul'turnykh transformatsii migratsionnykh protsessov v XX-XXI vv.: avtoref. diss. ... kand. filos. nauk [Peculiarities of Sociocultural Transformations of Migration Processes in the XX-XXI Centuries: Abstract of Thesis of PhD in Philosophy]. Velikii Novgorod, $26 \mathrm{p}$.

Zamaraeva, Iu.S. (2013). Vozmozhnosti sovremennykh kul'turnykh issledovanii dlia razvitiia teologicheskikh uchebnykh distiplin v rossiiskikh universitetakh [Possibility of Contemporary Arts Research for Development of Theological Training Disciplines in Russian Universities], In Modern Problems of Science and Education, 3, 413.

Zamaraeva, Iu.S. (2014a). K voprosu o vozdeistvii global'nykh transformatsii na korennye narody Severa, kompaktno prozhivaiushchikh v regionakh Rossiiskoi Federatsii [On the Impact of Global Transformations on the Indigenous Peoples of the North Living in Compact Communities in the Regions of the Russian Federation], In International Journal of Applied and Fundamental Research, 5-1, 113-116.

Zamaraeva, Iu.S. (2014b). Osobennosti etnicheskoi migratsii v sotsial'no-psikhologicheskom vospriiatii (na material analiza rezul'tatov eksperimenta po metodike "seriinye tematicheskie assotsiatsii”) [Peculiarities of Ethnic Migration in Socio-Psychological Perception (Based on the 
Analysis of the Results of "Serial Thematic Associations" Experimental Procedure)], In Sociodynamics, 9, 63-82.

Zamaraeva, Iu.S., Kistova, A.V., Pimenova, N.N., Seredkina, N.N. (2015). Taymyr Reindeer Herding as a Branch of the Economy and a Fundamental Social Identification Practice for Indigenous Peoples of the Siberian Arctic, In Mediterranean Journal of Social Sciences, 6 (3), 225-232.

Zhidkov, V.S. (2001). Gosudarstvennaia kul'turnaia politika [State Cultural Policy], In Orientiry kul'turnoi politiki [Guidelines of Cultural Policy], 6, 10-15.

Ziiatdinova, Iu.E. (2005). Dinamika kul'turnykh potrebnostei I kul'turnaia politika v sovremennoi Rossii: dis. ... kand. kul'turol.. nauk [Dynamics of Cultural Needs and Cultural Policy in Modern Russia: Thesis of PhD in Cultural Studies]. Moscow, 135 p.

\section{Трансформация роли}

\section{государственной культурной политики}

в период новейшей истории России

В.С. Лузан

Сибирский федеральный университет Россия, 660041, Красноярск, пр. Свободныгй, 79

В статье предпринята попьтка раскрыть трансформацию роли государственной культурной политики Российской Федерации в период новейшей истории начиная с первого десятилетия ХХІ века, когда окончательно оформилась действующая государственная система управления культурными прочессами, а также тех основных факторов, которые определяют данную трансформацию.

В статье отмечается, что анализ классических и современных отечественных исследований культурной политики подтверждает обоснованность обращения к междисциплинарному типу исследования данного многомерного объекта.

В заключение автором обозначены общие выводы и вероятные тенденции развития государственной культурной политики России в современной геополитической ситуации.

Ключевые слова: культурная политика, культура, самоидентификаиия, субъекты культурной политики, институты культуры, государство, органы власти, местное самоуправление.

Научная специальность: 24.00.01 - теория и история культуры. 